\title{
Folktales of International Justice
}

David Luban

Georgetown University Law Center, luband@law.georgetown.edu

This paper can be downloaded free of charge from:

https://scholarship.law.georgetown.edu/facpub/527

98 Am. Soc'y Int'I L. Proc. 182-185 (2004)

This open-access article is brought to you by the Georgetown Law Library. Posted with permission of the author. Follow this and additional works at: https://scholarship.law.georgetown.edu/facpub

Part of the Criminal Law Commons, and the International Law Commons 


\section{ACCOUNTABILITY FOR WAR CRIMES: WHAT ROLES FOR NATIONAL, INTERNATIONAL, AND HYBRID TRIBUNALS?}

\section{REMARKS BY LAURA DICKINSON*}

The issue of accountability for atrocities has been a major source of debate in international human rights and humanitarian law. Over the past fifteen years, we have seen the proliferation of mechanisms used to impose accountability. In the process, at least two different important dichotomies have emerged:

First, there has been debate about the types of accountability mechanisms, particularly where such mechanisms are located and how they are composed. Thus, we see a potential dichotomy between international forums such as the International Criminal Tribunal for the former Yugoslavia (ICTY) and the International Criminal Tribunal for Rwanda (ICTR) on the one hand, and domestic forums on the other.

Second, there has been concern about the goals of these accountability mechanisms: the possibility that the different types of mechanisms actually have different, perhaps even incompatible, aims. Thus there is perhaps a dichotomy between classic criminal trials, with their focus on individual culpability, and other transitional justice mechanisms, such as truth commissions, with their greater emphasis on broad historical truth-telling, or societal healing.

More recently, both of these dichotomies have become blurred, raising a new set of theoretical and practical issues. With regard to types of accountability mechanisms, we have seen the emergence of hybrids - courts that have both domestic and international actors, applying both domestic and international law, that are generally located in the country where the atrocities took place.

My own work has analyzed these hybrid courts with regard to their perceived legitimacy among both international and domestic constituencies; their ability to promote local capacitybuilding in the justice sector; and the likelihood that the norms articulated in them will penetrate the local society and become part of the culture. I have argued that in some post-conflict settings, along each of these three dimensions, hybrid courts may be superior to, though not necessarily an alternative to, purely international or purely domestic courts. ${ }^{1}$

With regard to the goals of the different mechanisms, scholars have increasingly emphasized the fact that each mechanism serves multiple goals. Trials, for example, may involve both individual accountability, and broad historical truth-telling and societal reconciliation; likewise, truth commissions need not involve amnesty from criminal prosecution; and so forth.

The establishment of the International Criminal Court (ICC) adds a new dimension to both the dichotomy about the type of accountability mechanism to be used and the dichotomy about the goals such mechanisms should pursue. With regard to mechanisms, now that the ICC exists some argue that, at least in some cases, anything less than an international trial is inadequate, even though the ICC is likely never to try more than a small number of perpetrators. With regard to goals, the ICC, as a criminal court, seems to be built along the classic criminal justice model, but to the extent that its ambitions include some of the broader aims of transitional justice and human rights, there may be some tension.

Thus, as these various mechanisms have evolved, we see tensions involving the blurring of both the types of mechanisms to be pursued and the appropriate goals of accountability

\footnotetext{
"Associate Professor of Law, University of Connecticut School of Law.

${ }^{1}$ See, e.g., Laura A. Dickinson, The Promise of Hybrid Courts, 97 AJL 295 (2003).
} 
mechanisms, and how (if at all) both the various types and the various goals might be harmonized to work together. This panel will explore these questions.

First, we will hear from David Luban, who will address the first dichotomy, arguing against the idea that only international courts can provide appropriate accountability for atrocities. Instead, he will tell several "folktales of justice," to use Robert Cover's famous phrase, ${ }^{2}$ in order to argue for what he calls universal vigilante jurisdiction. Going back to the very definition of what it means to commit a crime against humanity, Luban argues that any state could seek to redress such crimes.

Next, we will hear from Allison Danner, who will address the second dichotomy, noting some of the consequences that arise from the competing goals of postconflict justice. For example, the human rights and transitional justice model might be seen as in tension with the individual criminal accountability model. She will speak about that tension and argue that the values of individual criminal responsibility ought to take precedence in any criminal proceeding, whether domestic, international, or presumably hybrid, but particularly in international trials, which may be more susceptible to being captured by concerns beyond classic criminal justice.

Then we will have two case studies from two people who have been actual participants in accountability mechanisms: first, Judge Patricia Wald, formerly a federal judge on the U.S. Court of Appeals for the D.C. Circuit and on the ICTY, and now at the Open Society Institute; and second Bill Schabas, a professor at the National University of Ireland and currently a member of the Sierra Leone Truth and Reconciliation Commission.

Judge Wald will discuss why the ICTY model likely will not be repeated and offer some conclusions about the role the ICC might play, particularly in relation to other accountability mechanisms. Professor Schabas will discuss the relationship between the truth commission in Sierra Leone and the hybrid court there. Thus, he will in a sense address both dichotomies by looking at the relationship between two accountability mechanisms that have different aims and are being played out in different forums. His is thus a useful concluding paper for the panel.

\section{FoLKTALES OF INTERNATIONAL JUSTICE}

\section{by David Luban*}

When Laura Dickinson asked me to participate on this panel, she very nicely said that she hoped I could bring a different perspective to the discussion. I thought I knew what she meant. The other panelists share a profound knowledge of how international criminal-law institutions work. My "different perspective" would therefore be the perspective of abject ignorance.

Taking comfort from the Socratic dictum that there is wisdom in knowing what you do not know, I accepted the invitation because it gives me the opportunity to pose questions rather than proposing answers. I will raise my questions by examining some stories-what the late Robert Cover called Folktales of Justice-about the nature of legal institutions, in order to tease out some understanding of their aims. ${ }^{1}$ It is, after all, folktales and myths (even more than arguments) that reflect the moral intuitions that stand at the base of all legal institutions.

The first is a nonmythic, entirely true-to-life story: It is well-known that in the wake of the Armenian genocide of 1915 , the Allies originally hoped to put its perpetrators on trial for violating "the laws of humanity." The project was scuttled in the face of American objections

\footnotetext{
${ }^{2}$ See Robert Cover, The Folktales of Justice: Tales of Jurisdiction, in NARRATIVE, VIOLENCE, AND THE LAW: THE ESSAYS OF ROBERT COVER 173 (Martha Minow et al. eds. 1992).

- Frederick Haas Professor of Law, Georgetown University Law Center.

' Robert S. Cover, The Folktales of Justice: Tales of Jurisdiction, in NARRATIVE, VIOLENCE, AND THE LAW: THE ESSAYS OF ROBERT COVER (Martha Minow et al. eds. 1992).
} 
that the laws of humanity are entirely too vague to form appropriate predicates for criminal trials. In 1921, an Armenian survivor named Tehlirian gunned down the main organizer of the genocide on the streets of Berlin. Tehlirian was only seventeen years old then and he lived until 1979. Last semester, a law student emailed me a photograph of Tehlirian's tomb, whichoddly-is in Fresno, California. The inscription reads, in English and Armenian: "This monument has been erected by the Armenian people in memory of Soghomon Tehlirian, the national hero who on March 15, 1921, brought justice upon Talaat Pasha, a principal Turkish perpetrator of the Armenian genocide of 1915, which claimed the lives of 1,500,000 Armenian martyrs." If the law will not bring justice, the monument seems to say, then justice will fall to vigilantes like Tehlirian, or Shmuel Schwartzband, the young Jew who gunned down the orchestrator of the 1919 Ukrainian pogroms on the streets of Paris, five years after Tehlirian killed Talaat Pasha.

Justice, on this view, amounts to accountability and punishment. If states find accountability and punishment too inconvenient to deliver, vigilantes will rightly take justice into their own hands. Grotius wrote that an "open and conspicuous" punishment, which "may deter others from the commission of the same crimes . . may be inflicted by any . . individual." "A vindictive punishment," he adds, "inflicted by an injured individual or any other person ... has nothing unlawful in it, considering the law of nature by itself."

According to Samantha Power, the assassination of Talaat Pasha piqued the interest of a twenty-one-year-old law student named Raphael Lemkin, who wondered why legal punishment had never fallen on the murderers of the Armenians. In Lemkin's bewildered words, "It is a crime for Tehlirian to kill a man, but it is not a crime for his oppressor to kill more than a million men? This is most inconsistent." "That observation launched Lemkin's incredible career, which, as we all know, led him to coin the word "genocide," to define it and theorize it, and to lobby for the General Assembly resolution against genocide and the Convention Against Genocide. In a sense, Tehlirian's thirst for accountability, channeled through Lemkin's passion, stands at the fountainhead of the international criminal law project as we know it today. The project, this story suggests, arises not from statecraft but from what Grotius thinks is a more basic and primitive source: vigilante jurisdiction. Vigilantism delivers accountability in its purest, most unvarnished, form. ${ }^{5}$

Whose vigilantism, however? For Lemkin, genocide is a universal crime, a "crime against the human status" (to quote the Nuremberg prosecutor François de Menthon) which offends against all humankind. The phrase "crimes against humanity" likewise signifies crimes that offend against the human status and that all humankind shares an interest in repressing. The same is true of grave breaches of the Geneva Conventions: although the Conventions do not say so explicitly, they too are universal crimes.

That implies that anyone might have murdered Talaat Pasha or the Ukranian pogromist Petliura. But of course, "anyone" did not. It was an Armenian who murdered Talaat and a Jew who killed Petliura. And it was what Tehlirian's tomb calls "the Armenian people," or some subset of them, that erected the monument to Tehlirian. Humanity erected no such tomb. The student who sent me the photo was, you will not be surprised to learn, of Armenian descent. No one but Armenians visits Tehlirian's tomb.

Already, we can hear a question that animates the decision between international and universal-jurisdiction tribunals, on the one hand, and territorial tribunals on the other. The question is: Who holds the right to punish? In Grotius's terms, is it "the injured individual" or "any other person"? When German passersby tackled Tehlirian after the shooting, he shouted in broken

\footnotetext{
${ }^{2}$ Hugo Grotius, The Law of War and Peace [De Jure Belli ac Pacis] 228, bk. II, ch. 20, sec. VII (A.C. Campbell trans., 1901).

${ }^{3}$ Id.

${ }^{4}$ Samantha Power, "A Problem from Hell": America and the Age of Genocide 17 (2002).

5 I develop these ideas in David Luban, $A$ Theory of Crimes Against Humanity, 29 YALE J. INT'L L. 85, 124-40 (2004).
} 
German that he and Talaat were both foreigners, so "it's nothing to do with you."6 Who was right, Tehlirian or Lemkin and Grotius? They, after all, believed that Talaat Pasha's crime has everything to do with everyone.

Vigilantism is not an idea that sits comfortably with an audience of lawyers. Crucially, Grotius recognizes that the accountability project cannot be left in the hands of vigilantes. He writes: "as our judgment is apt to be biased .. . judges have been appointed, whereby the natural liberty of personal redress, originally allowed to individuals, was abolished, or at least abridged."7 The vigilante jurisdiction must be delegated to the state.

Consider a second story, Ariel Dorfman's powerful drama of transitional justice, Death and the Maiden. Paulina, a torture victim of the Pinochet dictatorship, manages to capture the man she believes raped her during her captivity. She holds him at gunpoint and demands that he confess. Her husband, a prominent human rights lawyer who has just been appointed to the new Truth Commission, is appalled at the thought that Paulina might kill him. Paulina was blindfolded during her torture and she recognizes the man only by his voice. Her husband warns, "A vague memory of someone's voice is not proof of anything, Paulina .... What can he confess if he's innocent?" To which she replies, bluntly: "If he's innocent? Then he's really screwed."8 For obvious reasons, that answer seems totally unacceptable. As Grotius suggests, the aim of tribunals is not simply to create accountability, but equally to protect innocent suspects from justice-seekers. ${ }^{9}$

That insight is inherent as well in a third folktale of justice, this time one of humanity's primordial myths of the origin of punishment. In the Bible, after Cain commits the world's first murder, against his brother Abel, God punishes Cain with banishment. "[Y]our brother's blood cries to Me from the ground. Therefore you shall be more cursed than the ground, which opened its mouth to receive your brother's blood from your hand. ... You shall become a ceaseless wanderer on earth." ${ }^{10}$ Cain's homicide makes him unfit to inhabit society; God therefore removes him from society. Interestingly, in the first murder case ever, God does not impose capital punishment.

But Cain immediately recognizes the problem inherent in his exile: "[A]nyone who meets me may kill me."11 When organized society withdraws its protection, he becomes fair game for vigilantes. And the vigilantes will punish him even more harshly than what God has deemed a just punishment: they will inflict death where God proclaimed only exile. So God reassures Cain: He will carry a mark signifying that whoever kills him will suffer sevenfold punishment.

Implicit in the story is a critique of vigilantism. Vigilantes cannot be counted on to deliver just punishment; even criminals have to be protected against them. Vigilantes may deliver disproportionate punishment, as in the Cain and Abel story; or they may punish the innocent, as Paulina's confession that if the doctor is innocent he's really screwed suggests. Hence the second question addressed by today's panel: Which form of tribunal can best be counted on to fulfill the precepts of natural justice, warding off unjust or excessive punishment?

There is another problem with vigilantism, and more generally with the quest for accountability that vigilantism represents: not the problem of unjust punishment, but the problem of endless vendetta. Here the archetype is Aeschylus' Eumenides, the final play of the Oresteian trilogy. The play offers literature's most famous myth of the origin of the legal system. You will recall the story: King Agamemnon has killed his own daughter in response to a prophecy. In revenge, his wife Clytemnestra murders Agamemnon. In turn their son Orestes takes vengeance

\footnotetext{
${ }^{6}$ POWER, supra note 4, at 1

${ }^{7}$ GROTIUS, supra note 2.

${ }^{8}$ ARIEL DORFMAN, DEATH AND THE MAIDEN, act 1, sc. 4; act 2, sc. 1.

${ }^{9}$ See David Luban, On Dorfman's Death and the Maiden, 10 YALE J. L. \& HUMAN. 115 (1998).

${ }^{10}$ Gen. 4:10-12 (Jewish Publication Society trans., 1992).

"Id. at 4:14.
} 
by murdering his mother. At that point, the Furies-the primordial goddesses of revengepursue Orestes for his crime. He flees to Athens, where the goddess Athena sets up a trial, the first ever, over whether their pursuit is right. The Furies argue their own case, and Apollo represents Orestes.

The legal issue they debate is which is worse, the murder of a father or of a mother? Apollo, a divine sexist, insists that murdering a father is worse, so that Orestes was right to avenge it. The Furies side with the right of mothers. The jury divides evenly. Athena, far from a neutral, impartial judge, breaks the tie, declaring that she is "for the male with all my soul."12 She persuades the Furies to give up the accountability project and instead become protectresses of the city. The Areopagite court takes over the Furies' profession. Law interrupts the cycle of vengeance and retribution, and the chorus underlines the point. It prays that the dry dust should never drink "the blood of citizens through passion for revenge and bloodshed for bloodshed." 13

Strikingly, even though Aeschylus obviously likes the outcome, he makes it clear that the Furies lost their case only because Apollo and Athena cheated. It was the Furies who had established law on their side. As I read the story, its fundamental message is that breaking the cycle of vengeance is more important than holding the guilty accountable, that legal systems exist not so much to do justice as to water it down in the name of peace and order. ${ }^{14}$ Legal systems, Aeschylus seems to say, always generate an accountability deficit-and they always should. If they did not, the dry dust would be soaked forever with the blood of citizens.

The questions this insight leaves us with are obvious. First, are peace and justice the only alternatives? Second, is peace really more important than justice? Third, if it is, what becomes of the world's Paulinas? Today, ten years after the genocide, do Rwandan rape victims truly have to live a hundred yards from their rapists? And fourth, is the role of states and the international society of states to create accountability or to dilute it?

Let us go back through the stories to see what they tell us about the goals of tribunals. The story of Tehlirian and Lemkin points to the goal most obvious in the project of international criminal law: accountability. But accountability is not the only goal. The Cain and Abel story, like Death and the Maiden, reveals a second, perhaps equally important goal: protection of suspects. The Oresteia proposes a third goal: peace, even at the cost of accountability.

The stories, if we take them seriously, tell us even more, however. If Aeschylus is right, creating accountability for slaughter is not really an interest of states; nor is it obviously an interest of the international society of states. ${ }^{15}$ Few today, indeed, should deny that states are only lukewarm about the accountability project. They condemn universal crimes in the abstract but they seldom intervene to stop them. Nor should we overlook that only two of the world's ten most populous states have ratified the Treaty of Rome, and the states-parties represent less than half the world's population.

On the other hand, if Lemkin and Grotius are right, even if states settle for an accountability deficit, human beings should not. Human beings, not states, share an interest in repressing the great crimes against the human status. That interest is, fundamentally, a vigilante jurisdiction. It is less clear, however, whether all human beings share the penal interest, or if Tehlirian was right that it is a matter for the victim's community only. That is perhaps the key question for today's panel. Finally, Dorfman's cautionary drama, like the primordial story of Cain and Abel, offers a criterion to judge the legitimacy of tribunals - any tribunals, international, domestic, or third-party: the extent to which they offer the protections of natural justice for the defendants they judge. Provided they meet that criterion, at bottom any court might do.

\footnotetext{
${ }^{12}$ AESCHYLUS, Eumenides, in AESCHYLUS I: ORESTEIA 169, 11. 737-38 (Richard Lattimore trans., 1953).

${ }^{13}$ Id., 11. 979-82.

${ }^{14}$ I elaborate on this interpretation in DAVID LUBAN, LEGAL MODERNISM 298-321 (1994). This is a revised version of David Luban, Some Greek Trials: Order and Justice in Homer, Hesiod, Aeschylus and Plato, 54 TENN. L. REV. 279 (1987).

15 See Luban, supra note 5, at 124-37.
} 


\title{
JoInt CRIMINAL ENTERPRISE AND CONTEMPORARY INTERNATIONAL CRIMINAL LAW
}

\author{
by Allison Marston Danner
}

As the title of this panel suggests, debates about accountability for mass atrocities often center on selection of the appropriate legal forum, whether that be an international tribunal, a hybrid tribunal, a truth commission, or a domestic prosecution. Despite this dizzying array of options, all these proceedings share one important principle: each relies-at least in part-on international criminal law as its source of substantive law. While hybrid and domestic trials may also include charges drawn from domestic criminal codes, all of the major institutions established in the past ten years to address past atrocities include within their jurisdiction crimes originating from international criminal law. ${ }^{1}$ This propagation of international criminal law renders its past and future development a critical concern.

International criminal law is a complex body of law that defies easy categorization. It can be understood as a direct outgrowth of international humanitarian law. ${ }^{2}$ International criminal law has also been described as a hybrid body of law employing principles drawn from the civil and common law modes of criminal adjudication. ${ }^{3}$ These portrayals, however accurate, are incomplete. They fail to capture other influences-namely domestic criminal law, human rights law, and transitional justice principles-that have played, and continue to play, an important role in the development of contemporary international criminal law.

My remarks here summarize a larger project undertaken with Professor Jenny Martinez. ${ }^{4}$ Our project has two principal goals: First, it describes the distinguishing features of the criminal law, human rights, and transitional justice influences that we believe shape contemporary international criminal law. It then applies those influences to two key liability doctrines within international criminal law: joint criminal enterprise and command responsibility. My remarks here do not attempt to describe the project in its entirety; instead, they briefly set out our vision of the major influences shaping international criminal law and their application to the doctrine of joint criminal enterprise.

Describing international criminal law as a confluence of principles drawn from domestic criminal law, human rights, and transitional justice principles may be seen as reductive. To some extent, the categories overlap. International human rights law, for example, includes

\footnotetext{
Assistant Professor of Law, Vanderbilt University Law School.

${ }^{1}$ Rome Statute of the International Criminal Court, July 17, 1998, arts. 5-8 (genocide, crimes against humanity, and war crimes), UN Doc. A/CONF.183/9*(1998), reprinted in 37 ILM 999 (1998), corrected through May 8, 2000, by UN Doc. CN.177.2000.TREATIES-5; Statute of the Special Court for Sierra Leone, arts. $2-4$ (crimes against humanity and war crimes), available at http://www.sc-sl.org/; Regulation No. 2000/15 on the Establishment of Panels with Exclusive Jurisdiction Over Serious Criminal Offences, sec. 1.3, UNTAET/Reg/2000/15 (June 6, 2000) (East Timor) (genocide, crimes against humanity, and war crimes), available at $<\mathrm{http} / / \mathrm{www} . \mathrm{un}$. org/peace/etimor/untaetR/ Reg0015E.pdf>; Draft Agreement Between the United Nations and the Royal Government of Cambodia Concerning the Prosecution under Cambodian Law of Crimes Committed during the Period of Democratic Kampuchea art. 9 (genocide, crimes against humanity, and war crimes) (Mar. 17, 2003), available at <http://www.yale.edu/cgp/ Cambodia\%20Draft\%20Agreement\%2017-03-03.doc >; Statute of the International Criminal Tribunal for the Former Yugoslavia arts. 2-5 (genocide, crimes against humanity, and war crimes), in Report of the Secretary-General Pursuant to Paragraph 2 of Security Council Resolution 808 (1993), UN Doc. S/25704 (1993), reprinted in 32 ILM 1159 (1993), available at $<\mathrm{http}: / \mathrm{www}$.un.org/icty/legaldoc/index.htm $>$ [hereinafter ICTY Statute]; Statute of the International Criminal Tribunal for Rwanda, arts. 2-4 (genocide, crimes against humanity, and war crimes), SC Res. 955, annex, UN SCOR, 49th Sess., Res. \& Dec., at 15, UN Doc. S/INF/50 (1994), reprinted in 33 ILM 1598 (1994), available at <http:/www.ictr.org/ENGLISH/basicdocs/statute.html> [hereinafter ICTR Statute].

${ }^{2}$ The statutes of the ICTY and ICTR, for example, call for the prosecution of "serious violations of international humanitarian law." ICTY Statute, supra note 1, art. 1; ICTR Statute, supra note 1, art. 1.

${ }^{3}$ See, e.g., Robert Christensen, Getting to Peace by Reconciling Notions of Justice: The Importance of Considering Discrepancies Between Civil and Common Legal Systems in the Formation of the International Criminal Court, 6 UCLA J. INT'L L. \& FOREIGN. AFF. 391 (2001); Faiza Patel King \& Anne-Marie LaRosa, Jurisprudence of the Yugoslavia Tribunal: 1994-1996, 8 EUR. J. INT'L L. 123, 125 (1997).

${ }^{4}$ See Allison Marston Danner \& Jenny S. Martinez, Guilty Associations: Joint Criminal Enterprise, Command Responsibility, and the Development of International Criminal Law, 93 CAL. L. REV. (forthcoming Jan. 2005).
} 
principles governing the criminal trial, and the criminal trial is an important element of transitional justice mechanisms. Nevertheless, certain essential features of each of these approaches can be distilled and compared.

Domestic criminal law ${ }^{5}$ focuses on individual wrongdoing as a necessary prerequisite to the imposition of criminal punishment. The criminal trial centers on the mental state and actions of the perpetrator: the experience of the victim is, in important ways, peripheral to the search for criminal wrongdoing. International criminal adjudication has implicitly, and occasionally explicitly, adopted this orientation. ${ }^{6}$ International criminal law instantiates this focus on individual wrongdoing through a variety of substantive and procedural devices. ${ }^{7}$ At bottom, however, these doctrines simply reinforce the principle of individual culpability and the concomitant avoidance of guilt by association.

By contrast, human rights proceedings are, generally speaking, centered on the wrongs inflicted on the victim. The substantive norms of international human rights law are often broadly interpreted to ensure that harms to victims are recognized and remedied, and that over time progressively greater respect for human dignity and freedom is realized. ${ }^{8}$ In many human rights proceedings, the culpability of the individual wrongdoer is relatively unimportant. Indeed, establishing the identity of the individual wrongdoer may not be necessary in order to find that the victim's human rights have been violated. ${ }^{9}$

In contrast to criminal and human rights law, "transitional justice" does not refer to a body of substantive law but instead to a variety of legal mechanisms used to mark political transitions. ${ }^{10}$ The proceedings may consist, for example, of criminal trials, truth commissions, or indigenous mechanisms. ${ }^{11}$ Because of their political function, these proceedings share common elements. They seek to provide a historical record of a period; often truth-telling is a primary goal. Generally they also seek to establish that individuals-not entire societies-are responsible for the wrongs of the past. ${ }^{12}$ In practice, these mechanisms often attribute responsibility for past wrongdoing to the political leaders of the period.

It is our contention that these three influences-sketched briefly here-play an important role in the development of many doctrines of contemporary international criminal law, including joint criminal enterprise. Joint criminal enterprise (JCE) is a theory of liability that has been most extensively elaborated by the prosecutors and judges at the International Criminal Tribunal for the former Yugoslavia (ICTY). ${ }^{13} \mathrm{JCE}$ allows individuals to be convicted of crimes that they did not physically commit. Although JCE has several variants, it essentially requires

\footnotetext{
${ }^{5}$ By this phrase, I refer to certain general features common to most sophisticated municipal criminal law systems, particularly the principle of individual culpability. See Mirjan Damaška, The Shadow Side of Command Responsibility, 49 AM. J. COMP. L. 455, 470 (2001).

${ }^{6}$ Prosecutor v. Tadic, Judgement, Appeals Chamber, Case No. IT-94-1-A para. 186 (July 15, 1999) [hereinafter Tadic V] (stating "The basic assumption must be that in international law as much as in national systems, the foundation of criminal responsibility is the principle of personal culpability: nobody may be held criminally responsible for acts or transactions in which he has not personally engaged or in some other way participated").

${ }^{7}$ The rule of strict construction of penal statutes represents one such device. See, e.g., Prosecutor v. Kayishema \& Ruzindana, Judgement, Trial Chamber, Case No. ICTR-95-1-T para. 103.

${ }^{8}$ See Laurence R. Helfer, Overlegalizing Human Rights: International Relations Theory and the Commonwealth Caribbean Backlash Against Human Rights Regimes, 102 CoLUM. L. REV. 1832, 1887 (2002). In criminal law trials, by contrast, the offenses are, at least in theory, strictly construed in favor of the defendant.

${ }^{9}$ See, e.g., Velasquez Rodriguez Case, Judgement, Inter-Am. C.H.R. (Ser. C), No. 4, para. 172 (1988).

${ }^{10}$ See generally, RUTI G. TEITEL, TRANSITIONAL JUSTICE (2001); TRANSITIONAL JUSTICE AND THE RULE OF LAW IN NEW DEMOCRACIES (A. James McAdams ed., 1997); TRANSITIONAL JUSTICE: HOW EMERGING DEMOCRACIES RECKON WITH FORMER REGIMES (Neil J. Kritz, ed. 1997).

"The gacaca proceedings used in Rwanda, for example, provide an example of such an indigenous mechanism. See Mark A. Drumbl, Toward a Criminology of International Crime, 19 OHIO ST. J. ON DiSP. RESOL. 263, 275 (2003).

${ }^{12}$ See Antonio Cassese, Reflections on International Criminal Justice, 61 MOD. L. REV. 1, 6 (1998).

${ }^{13}$ Joint criminal enterprise is also referred to by other terms, such as "common purpose" and "common plan" liability. See Prosecutor v. Radoslav Brdanin \& Momar Talic, Decision on Form of Further Amended Indictment and Prosecution Application to Amend, June 26, 2001, para. 24, 2001 WL 1793829.
} 
prosecutors to prove that a group of people had a common plan, design, or purpose to commit a crime; that the defendant participated in some fashion in the common plan; and that the defendant intended the object of the common plan. ${ }^{14}$ If the prosecution can prove these elements, the defendant can be convicted of all completed crimes within the scope of the common plan, and all crimes that he did not intend but that were a foreseeable consequence of the common plan.

Joint criminal enterprise does not appear in the statute of the ICTY. It was recognized by the ICTY Appeals Chamber as implicitly falling within the statute in part based on the Appeals Chamber's reading of the statute's object and purpose, which it described as ensuring that "all those who have engaged in serious violations of international humanitarian law, whatever the manner in which they may have been perpetrated, or participated in the perpetration of those violations, must be brought to justice."15

It is our contention that the development of joint criminal enterprise bears indications of the importance of criminal law, human rights, and transitional justice principles in contemporary international criminal law. With reference to the criminal law paradigm, we note assertions by the ICTY judiciary that JCE is a form of individual liability. ${ }^{16}$ This requirement is doctrinally enforced through the twin requirements that the individual must intend the criminal object of the joint criminal enterprise and must participate in some way in the accomplishment of that objective. From the human rights approach, we observe the willingness of the ICTY Appeals Chamber to go beyond the text of the statute and adopt this far-reaching theory. The language of Tadic suggests that the Appeals Chamber decision arose from a victim-centered search for accountability that seeks to ensure that all perpetrators may be found guilty of crimes within the ICTY's jurisdiction. From transitional justice, we find there is an emphasis on using JCE to prosecute the senior leadership. Slobodan Milošević, for example, stands accused of participating in three massive JCEs. ${ }^{17}$ Furthermore, joint criminal enterprise allows individuals to be found responsible for broad swaths of wrongdoing, which arguably furthers the transitional justice goal of disclosing the full extent of crimes perpetrated in the names of former leaders.

While these three influences can be observed in the development of joint criminal enterprise, the doctrine has in practice strayed far from the focus on individual culpability that distinguishes the criminal law paradigm. Because there is usually no minimum quantum of contribution an individual must make to a JCE, international prosecutors can allege joint criminal enterprises of enormous scope. There appears to be no reason, for example, why the ICTR Prosecutor could not allege that the elimination of moderate Hutus and Tutsis in Rwanda was itself the object of a massive criminal enterprise. Through this charge, the prosecution could argue that each ICTR defendant who intentionally participated in the genocide and who foresaw the killings that in fact occurred should be found liable for the murder of hundreds of thousands of people.

In practice, JCE represents an enormous transfer of power from international judges to prosecutors, who have enormous discretion to decide how much wrongdoing to tie to any particular defendant. Because the doctrine is so loose, JCE approaches dangerously close to guilt by association. This is particularly troubling in light of the still-tenuous legitimacy of international criminal law.

Joint criminal enterprise also illustrates the potential dangers posed by the proliferation of international criminal law. Substantive international criminal law is used in many forums,

\footnotetext{
${ }^{14}$ See Prosecutor v. Multinovic et al., Decision on Dragoljub Ojdanie's Motion Challenging Jurisdiction-Joint Criminal Enterprise, Appeals Chamber, Case No. IT-99-37-AR72 (May 21, 2003).

${ }^{15}$ Tadic V, supra note 6, para. 190.

${ }^{16}$ See, e.g. Prosecutor v. Multinovic et al., supra note 14, para. 26.

${ }^{17}$ Prosecutor v. Milosevic, Initial Indictment, Case No. IT-01-51-I para. 6(Nov. 22, 2001) Prosecutor v. Milosevic, First Amended Indictment, Case No. IT-02-54-T para. 6 (Oct. 23, 2002); Prosecutor v. Milosevic et al., Second Amended Indictment, Case No. IT-99-37-PT para. 16 (Oct. 16, 2001).
} 
international and national, and the complementarity regime of the International Criminal Court should only accelerate this trend. Not all these forums will share the human rights and transitional justice goals of the original courts in which the doctrine may have been developed. Two indictments recently issued by the United States Military Commissions established to try alleged terrorists, for example, appear to employ a version of joint criminal enterprise.

These indictments accuse two individuals of conspiracy to commit a variety of crimes, including attacking civilians, by "willfully and knowingly join[ing] an enterprise of persons who shared a common criminal purpose."18 Human rights advocates may applaud when an international court uses an expansive version of JCE doctrine to hold a particular defendant liable for the range of crimes associated with regional ethnic cleansing in which he played some part. But they may wish the doctrine had been more carefully defined when it is later used by a national government to suggest that all persons who provide any sort of support to a terrorist organization, however loosely defined, become liable for all crimes committed by its members.

We hope that international judges and prosecutors will be sensitive to the influences that may guide their decision-making. We believe that not all these principles are equally suitable for forums premised on a criminal law mode that promises to adjudicate individual criminal responsibility. In the case of joint criminal enterprise, the influence of human rights and transitional justice principles may have gone too far.

\section{TruTh Commissions aNd Courts Working in PARALlel: THE SIERRA LEONE EXPERIENCE}

\section{by William A. Schabas*}

The Sierra Leone Truth and Reconciliation Commission (TRC) was established in July 2002, pursuant to an act of the country's Parliament. ${ }^{1}$ It is expected to present its final report to the president of Sierra Leone in June 2004. The report will provide Sierra Leone with a detailed narrative of the country's history, focusing on the brutal civil war of the 1990s; analysis of various dimensions of political, economic and social life, with a view to understanding the causes of the conflict; and a series of findings and recommendations.

Perhaps the most distinctive feature of post-conflict justice in Sierra Leone is the parallel existence of a truth commission and an international tribunal, the Special Court of Sierra Leone. Traditionally, truth and reconciliation commissions have been viewed as an alternative to criminal justice that, sometimes only informally, replaces or at the very least suspends prosecutions. In Sierra Leone, the two institutions have operated contemporaneously.

This unprecedented experiment has revealed some of the tensions that may exist between the two approaches. Yet it has also demonstrated the feasibility of the simultaneous operation of an international court and a truth commission. The Sierra Leone experience may help us understand that post-conflict justice requires a sometimes complex mix of synergistic therapies, rather than a unique choice of one approach from a list of what some may see as essentially incompatible alternatives.

Sierra Leone's civil war began on March 23, 1991, when forces styling themselves the Revolutionary United Front (RUF) raided the town of Bombali, which is near the northern border

\footnotetext{
${ }^{18}$ United States v. Ibrahim Ahmed Mahmoud al Qosi, Charge: Conspiracy para. 18 (Feb. 24, 2004), available at $<$ http://www.defenselink.mil/news/Feb2004/d20040224Al Qosi.pdf>; United States v. Ali Hamza Ahmad Sulayman al Bahlul, Charge: Conspiracy para. 14 (Feb. 24, 2004), available at $<$ http://www.defenselink.mil/news/Feb2004/ d20040224Al Bahlul.pdf>.

* Professor of Human Rights Law, National University of Ireland, Galway, and Director, Irish Centre for Human Rights, and a member of the Sierra Leone Truth and Reconciliation Commission. This article is written in his private capacity; it does not necessarily reflect the views of the other commissioners or of the Commission.

1 Truth and Reconciliation Commission Act 2000, Supplement to the 131 SIERRA LEONE GAZETTE, No. 9.
} 
with Liberia. The formal beginning of the end of the conflict was the Lomé Peace Agreement of July 7, 1999, between the government of Sierra Leone and the RUF. ${ }^{2}$ The agreement provided a controversial amnesty for perpetrators of atrocities on all sides of the conflict. ${ }^{3}$ The Special Representative of the Secretary General of the United Nations, Francis Okelo, formulated a reservation to the amnesty provision, insisting that it could not apply to crimes against humanity and war crimes. ${ }^{4}$

The Lomé Peace Agreement pledged the establishment of a Truth and Reconciliation Commission (TRC or Commission), to be set up within ninety days. Although efforts were soon directed to this task, ${ }^{5}$ legislation for the purpose was not adopted by Sierra Leone's Parliament until February 22, 2000. Pursuant to section 6(1) of the Truth and Reconciliation Commission Act 2000, the Sierra Leone TRC was established

to create an impartial historical record of violations and abuses of human rights and international humanitarian law related to the armed conflict in Sierra Leone, from the beginning of the Conflict in 1991 to the signing of the Lomé Peace Agreement; to address impunity, to respond to the needs of the victims, to promote healing and reconciliation and to prevent a repetition of the violations and abuses suffered. ${ }^{6}$

A renewal of fighting in May 2000 stalled the creation of the TRC and also revived debate about the legitimacy of the amnesty. Responding to a request from the government of Sierra Leone, on August 14,2000, the Security Council supported the creation of a court to try "persons who bear the greatest responsibility" for serious violations of international humanitarian law and the laws of Sierra Leone and mandated the Secretary-General to negotiate an agreement with the government of Sierra Leone to this effect. ${ }^{7}$

The two organizations- the TRC and the Special Court--both became operational in mid2002. After a start-up phase that lasted several months, the Commission's actual activities began in December 2002. During a three-month statement-taking phase, approximately seven thousand victims and perpetrators were interviewed in all corners of the country. The detailed statements that emerged were used to identify "window cases" that became the focus of public hearings. The hearings phase started in April 2003 and concluded in early August with an appearance by the president of Sierra Leone, Alhaji Ahmad Tejan Kabbah.

In March 2003, the Special Court issued eight indictments against several obvious and wellknown suspects, including former RUF leader Foday Sankoh, former junta leader Johnny Paul Koroma, incumbent deputy defense minister Sam Hinga Norman, and erstwhile Liberian President Charles Taylor. Norman had been expected to meet with the TRC only days before he was arrested and detained. Since then, trial preparations have been underway and a variety of preliminary procedural matters have been litigated. The first trials began in June 2004. The TRC is expected to present its report by October 2004.

In a letter to the Security Council in 2001, as the court's legal framework was still being negotiated, Kofi Annan said that "care must be taken to ensure that the Special Court for Sierra Leone and the Truth and Reconciliation Commission will operate in a complementary and

\footnotetext{
${ }^{2}$ For discussion of the legal status of the agreement, see Prosecutor v. Kallon et al., Case Nos. SCSL-2004-15 and 16-AR72(E), Decision on Challenge to Jurisdiction (Lomé Accord Amnesty) (Mar. 13, 2004).

${ }^{3}$ Peace Agreement Between the Government of Sierra Leone and the Revolutionary United Front of Sierra Leone, Lomé, Togo (July 7, 1999), art. IX.

${ }^{4}$ Seventh Report of the Secretary-General on the United Nations Observer Mission in Sierra Leone, UN Doc. S/1999/836 (July 30, 1999).

${ }^{5}$ Richard Bennett, The Evolution of the Sierra Leone Truth and Reconciliation Commission, in UNAMSIL, TRUTH AND RECONCILIATION IN SIERRA LEONE 37-51 (2001).

${ }^{6}$ Truth and Reconciliation Commission Act 2000, available at <http//:www. sierra-leone.org/trcact2000.html $>$.

${ }^{7}$ UN Doc. S/RES/2000/1315. On the establishment of the Court, see Prosecutor v. Kallon et al., supra note 2, Decision on Constitutionality and Lack of Jurisdiction (Mar. 13, 2004).
} 
mutually supportive manner, fully respectful of their distinct but related functions." ${ }^{8}$ Once it became clear that the two institutions would operate in parallel, there was intense speculation about how they might interact. Those who were suspicious of truth commissions and oriented towards criminal prosecution saw an opportunity to marginalize the TRC, subordinating it to the court as a kind of investigative arm or grand jury. Those who favored restorative justice approaches responded by insisting upon the relevance of a strong and dynamic TRC as a complement to prosecution. Several nongovernmental organizations made detailed submissions directed at a formal "relationship agreement" between the two bodies.

The various proposals mainly attempted to govern the modalities of information sharing between the TRC and the Special Court. In practice everyone understood this would be a oneway street. It was quite unthinkable that the prosecutor of the Special Court-not to mention the defense-would share its files with the Commission. From the TRC standpoint, the concern was that access by the court to its materials would have a chilling effect on perpetrators who might otherwise have been tempted to cooperate with the Commission. For example, the Secretary-General indicated that the RUF was "receptive" to the TRC but that it had expressed "concern over the independence of the Commission and the relationship between it and the Special Court." According to Human Rights Watch, doubts about the ability of the TRC to obtain information in confidence "could potentially undermine the willingness of persons to come before the TRC to provide testimony." 10

In the end, there was never any agreement between the two bodies; nor was there any information-sharing. Neither institution showed any interest in cooperation. Both seemed to value polite, neighborly relations, nothing more. The prosecutor of the Special Court, David Crane, very helpfully declared that he was not interested in seeking information from the TRC, a move that may have reassured some perpetrators who were concerned that any information they might provide to the Commission would be used to build a case against them at the Special Court.

After the TRC concluded its public hearings in August 2003, some detainees of the Special Court asked to give public testimony to the TRC. Even more surprisingly, the Prosecutor then opposed the initiatives taken by the TRC with a view to facilitating such public hearings. A ruling by the court's president, Geoffrey Robertson, allowed defendants to appear before the Commission but did not authorize a public hearing. ${ }^{11}$ Deprived of the platform they had been seeking, the defendants ultimately refused to cooperate with the TRC. Unfortunately, the tensions generated by this litigation left a sour taste in relations between the TRC and the Special Court. In reality, it was little more than an incident in what had been an essentially serene relationship.

The TRC accomplished its mandate, although it suffered terribly from poor funding and administrative weaknesses. In particular, it was able to prompt the cooperation of many perpetrators, who testified to their deeds in public or private. In this respect, it was probably no better or worse than the many other truth commissions have been. There is nothing simple about convincing those who have committed atrocities to admit to their crimes. Moreover, the Sierra Leone TRC did not have the carrot of amnesty that the South African TRC had used as an incentive for perpetrator admissions.

\footnotetext{
${ }^{8}$ Letter dated January 12, 2001 from the Secretary-General to the President of the Security Council, UN Doc. S/2001/40, para. 9.

${ }^{9}$ Eleventh Report of the Secretary-General on the United Nations Mission in Sierra Leone, UN Doc. S/2001/857 (Sept. 7, 2001), para. 44.

${ }^{10}$ Human Rights Watch Policy Paper on the Interrelationship Between the Sierra Leone Special Court and Truth and Reconciliation Commission (April 18, 2002), at 2. See also Letter from PRIDE to ICTJ, quoted in Marieke Wierda et al., Exploring the Relationship Between the Special Court and the Truth and Reconciliation Commission of Sierra Leone, International Center for Transitional Justice paper (June 24, 2002), at 8.

11 Prosecutor v. Norman (Case No. SCSL-2003-08-PT), Decision on Appeal by the Truth and Reconciliation Commission for Sierra Leone ('TRC' or 'The Commission') and Chief Samuel Hinga Norman JP Against the Decision of His Lordship, Mr Justice Bankole Thompson, Delivered on October 30, 2003 to Deny the TRC's Request to Hold a Public Hearing with Chief Samuel Hinga Norman JP, Nov. 28, 2003.
} 
The willingness or reluctance of perpetrators to participate in accountability processes-be they truth commissions or courts-may have far less to do with promises of amnesty or threats of prosecution than many may think. Just as criminals often confess despite Miranda warnings about the right to silence, not to mention stern admonition from their lawyers, some perpetrators of serious human rights violations may feel the need to unburden themselves, to "tock dee troot" as they say in Krio, Sierra Leone's lingua franca. At the other extreme, there are those who are incapable of admitting to what they have done even when promised immunity from prosecution. This suggests that whether truth-telling does or does not work is unrelated to the threat of criminal trial.

\section{ACCOUNTABILITY FOR WAR CRIMES: WHAT ROLES FOR NATIONAL, INTERNATIONAL AND HYBRID TRIBUNALS?}

\section{by Patricia M. Wald}

The past ten years have seen an extremely fast-moving scenario in the introduction, revision, and possibly the rejection of individual accountability mechanisms for war crimes and crimes against humanity. In rapid succession (rapid at least for this line of work) we have seen the establishment of two United Nations Article VII Security-Council-based courts (Yugoslavia and Rwanda), several hybrid courts (Sierra Leone, East Timor, Kosovo, and Cambodia) melding national and international judges and law; some largely unsuccessful attempts by national courts to go it alone, and a plethora of truth and reconciliation commissions (TRCs)--some successful, some not-rejecting or supplementing the criminal law mode for confession and community penance. While it may be too early for final verdicts, we have some fairly steady indicators of where future courts of this kind may be headed.

I.

The first model-the pure UN Court--has proved too costly for its sponsors to repeat. Despite formidable achievements in the development of a war crimes and crimes against humanity jurisprudence, the trials in these courts have been unduly slow (though faster in recent years with the introduction of negotiated guilty pleas and other procedural reforms); Rwanda has suffered additionally from spates of corruption in its administration; and neither the International Criminal Tribunal for the former Yugoslavia (the ICTY) nor that for Rwanda (the ICTR) has made real contact with the populaces affected by their proceedings. They are perceived as distant and unconcerned with the effect of their activities upon victims.

As far as defusing tensions in the region, there is little evidence they have accomplished much. Indeed, under this original model the judges have little power to do so; it is the prosecutor who selects the cases (among "big fish" or "little fish" defendants, and among the ethnic warring groups). The judges are mainly receptors for the cases that come in over the transom. In at least one case at the ICTY the judges openly expressed their unhappiness with the prosecutor's choice of cases and refused to remand for a new trial, despite their ruling that the trial court had been wrong under the law in dismissing a genocide case.

I note that in the new International Criminal Court (ICC), Pretrial Chamber judges have more power at the edges to affect the choice of cases, which in turn may affect tension in the area. They can decide whether a state is capable and willing to prosecute the case itself (Rome Statute, art. 19) and that a case "is not of sufficient gravity to justify further action by the Court" (art. 17); and they can review the prosecutor's decision not to proceed with an investigation

\footnotetext{
- Chair, Open Society Justice Initiative; former Judge, International Criminal Tribunal for the former Yugoslavia; and former Chief Judge, U.S. Court of Appeals. D.C. Circuit.
} 
because it "would not serve the interests of justice" (art. 53). ${ }^{1}$ There are, furthermore, more provisions for active participation by victims in the proceedings, as well as the possibility of money reparations. All these may have some potential to reduce tension.

In all types of courts, selection of whom to prosecute and when can be potentially important for reducing tension. Indeed, there is a continuing conflict between those who believe criminal prosecution "for the sake of justice" is a paramount consideration at all times and those who believe that declining to prosecute, or even guaranteeing amnesty, may under certain conditions be a more desirable strategy in negotiating or implementing peace.

Everyone agrees that international criminal courts operate in an intensely political milieu and cannot escape political-in the broadest sense of the word-context in formulating prosecutorial strategies; that context may well include prospects for reducing tensions. The tribunals have affected events in the political arena. Indictments of former President Karadic meant he could no longer run for office or leave the region; the ICTY provided a forum for a new reform president of Croatia to reveal the misdeeds of his predecessor and also affected Milosevic's control over his home country and helped to legitimize the Kosovo interventions. Whatever the outcome, the ICTR helped disestablish Charles Taylor; and a tribunal could have a similar purging effect in Iraq.

On the other hand, a recent New York Times article on Mostar, a Bosnian city, ten years after the war, says the city has "two sets of nearly everything: hospitals, universities, primary schools, public transportation, even waste disposal services."2 Muslims and Croats do everything separately from the Serbs. The international administrator, Lord Ashdown, has tried to end this segregation by fiat but the success of his efforts is in doubt. "Most Bosnian Serbs and Bosnian Croats are not loyal to this country," a Sarajevo columnist opines. "They do not have the feeling that they belong to this state. Serbs look over the Drina to Belgrade, and Croats to Zagreb; foreigners don't understand that." Recent ethnic outbreaks in Kosovo between Serbs and Albanians send a similar message.

\section{II.}

Outreach efforts at all of the international courts so far appear to be primitive. The ICTY is gearing up for a more sophisticated program of discussions of specific completed cases in the actual localities involved, with the participants, prosecutors, and judges explaining the reasons for their actions. In Sierra Leone, the prosecutor made one-on-one efforts to contact people in the community before the trials began. In some countries, like Cambodia, where an Extraordinary Chamber is expected to begin next year, the majority of the population does not have television or cannot read, so alternative media like radio and street dramas are being considered. But there is widespread agreement that the role of the courts in vindicating past wrongs and bringing closure to victims is not being adequately plumbed by any existing court. In one sense, we do not really know what effect a vigorous outreach program to explain the tribunals' activities and their implications could have on tension reduction.

\section{III.}

There appears to be widespread agreement, after a decade of trial and error, that courts conducted inside the country where the atrocities took place are most likely to satisfy the involved populace's desire for justice, if . . . There are many big "ifs" here. Physical security of judges, prosecutors, defense counsel, and witnesses is a primary concern. These same players must be

\footnotetext{
${ }^{1}$ Rome Statute of the International Criminal Court, July 17, 1998, UN Doc. A/CONF.183/9* (1998).

${ }^{2}$ Nicholas Wood, Mostar Journal: An Effort to Unify a Bosnian Citie's Multiple Frictions, N.Y. TTMES, Mar. 15, 2004 , at A4.
} 
immune from overwhelming pressures from other parts of the national government if the trial is to be and to look impartial to the rest of the world as well as the home audience. In several nationally held trials, prosecutors have displayed inexplicable docility, witnesses have not been protected from intimidation, courtrooms have been filled with noisy and uncontrollable demonstrators for one side, and adequate resources have been withheld from the judges or court administrators.

Here the Iraq trial could be a trendsetter if properly conducted, showing that a fair trial may be held within a country soon after hostilities have ended. But, as I have said, there are many ifs. The success of nationally based models is still up in the air, although the ICC's complementarity principle is substantially based upon it. Finally, if trials are held nationally, there is a very significant role for nongovernmental organizations (NGOs) to monitor them to spot injustices and to report to the outside world what is happening. That is why it was especially disheartening to hear our own military tribunal had "no room at the inn" for NGOs.

IV.

There is a strong sentiment that even if war crimes trials are held in-country, the presence of international judges can help to (a) educate local judges on international law and minimal standards of fairness, (b) create an impression of impartiality, and (c) insulate local judges to some degree against intimidation from their own governments (the Cambodian law provides that there can be no decision without at least one international judge concurring). The Sierra Leone and Kosovo tribunals have also employed this mix. Iraq will not have international judges, but will have international advisors, which may go some way toward achieving these objectives.

Again, though, it is not enough to get judges from another country; the visiting judges should themselves be schooled in international law and standards. Some have suggested that a core group of international judges, and perhaps prosecutors, might rotate on such duties, bringing best practices from one tribunal to another. Another interesting suggestion is that in pursuit of its complementarity doctrine, the ICC could negotiate and actively assist good-faith national authorities in bringing their systems up to snuff so that trials may be held locally. Certainly a hybrid international court or a regional court ought to count as part of that system for complementarity purposes.

It is still not entirely clear whether TRCs could provide the basis for decisions by the ICC that complementarity applies, impelling them to decline to hear a case. But the ICC prosecutor appears to have adopted an approach of working with local governments to get their systems in shape rather than merely fighting off their efforts to resist ICC jurisdiction. Hopefully, as the ICC gets underway, principles or guidelines as to what constitutes "willing or able" national systems will emerge.

V.

The role of the truth and reconciliation commissions in all of this is another work very much in progress. Some of these - the prototypes in South Africa and in a few South American countries-have been very useful in eliciting admissions of responsibility from perpetrators of war crimes and crimes against humanity. In South Africa, though, the TRC was always backed by the threat of prosecution if the perpetrators did not make a full confession; even then it attracted mainly middle-level miscreants. In Sierra Leone, where the Special Court and the TRC operated simultaneously, the outcomes are reportedly mixed, though Professor Schabas can tell us much more. In other countries, TRCs have been feeble or even futile, under-resourced and distrusted.

The TRC mechanism has much potential, but how best to fit it into a total program for reconciliation is still an open question. My own belief is that it will seldom be enough on its own, 
but it may offer a constructive alternative for middle- and lower-level offenders when it is impossible to bring them all to trial. While it may be necessary to a national sense of justice to hold accountable in criminal trials the major instigators and planners of atrocities, for many victims it is just as important to face down the local village executor of those nefarious schemes and strategies. The varied experiences of the TRCs definitely need more study and experimentation.

In summary, it may be overoptimistic to expect international prosecutions and trials to reconcile as well as punish. They may be a necessary safety valve for collective resentments, but after a decade victims know these tribunals cannot give back homes, land, jobs, or lost relatives. Indeed, there is widespread disillusionment with courts generally in most parts of the world - -their corruption, inefficiency, and impossibility to access. Articulating relatively modest aims for international courts and creating a robust body of international humanitarian law for all courts to apply may be the best we can hope for, such as conducting honest trials as an example for local systems. They are not, however, the panacea for the world's wars.

Can reconciliation be possible without much deeper attention to the social and economic grievances giving rise to conflict? Most negotiated peaces after civil wars, we are told, end up in recurrences within several years, which is when tyrannical governments are most likely to come into being. Civil wars are on the rise, while international wars are on the wane; right now there are seventeen ethnic-based civil wars.

Resource shortages plague all international, as well as local, court systems. Voluntary UN assessments are an unsteady basis for future international courts. I have been told a global court fund is being talked about so these hybrid courts will not have to cut back too soon or too drastically from their original goals.

Hybrid courts and even indigenous mechanisms pose some risks for the traditional orientation of international law that we need to keep in mind. Will these courts apply domestic law at all, and will they apply it consistently with other international courts? Will local customary law, where it is applied, meet international standards in substance and in procedure? Should we care if it does not? Witness the current debate over use of the death penalty in Iraqi trials of Saddam Hussein and his lieutenants.

What does the withdrawal of America from the international court scene, as well as antiAmericanism in general, mean for the development of international humanitarian law and tribunals? Do we as Americans have the moral right to reject putting our citizens before courts we do not think are fair?

So, where are international courts going? Hybrid and regional courts (or indigenous courts) will be the trend, sometimes written into the peace treaties themselves. American dominance on substance and procedures will lessen. Resources will continue to be a problem. Hybrid courts with some international input will have more credibility if the input is informed.

The ICC may be a flagship of sorts but will have to pick its way warily between taking on hot-button issues and becoming politicized, and avoiding major conflicts and becoming irrelevant. Hopefully, the ICC can become a catalyst for beefing up local systems to meet minimal international standards.

In the end, internationalized courts will fashion a niche for themselves, but how much they can aspire to affect fundamental reconciliation, other than assuaging basic senses of injustice and ending the impunity of the worst offenders against humanity (not insignificant aims by any means), is still unclear at this juncture, as is the comparable effect of TRCs. 
Heinonline -- $98 \mathrm{Am}$. Soc'y Int'l. L. Proc. 1962004 